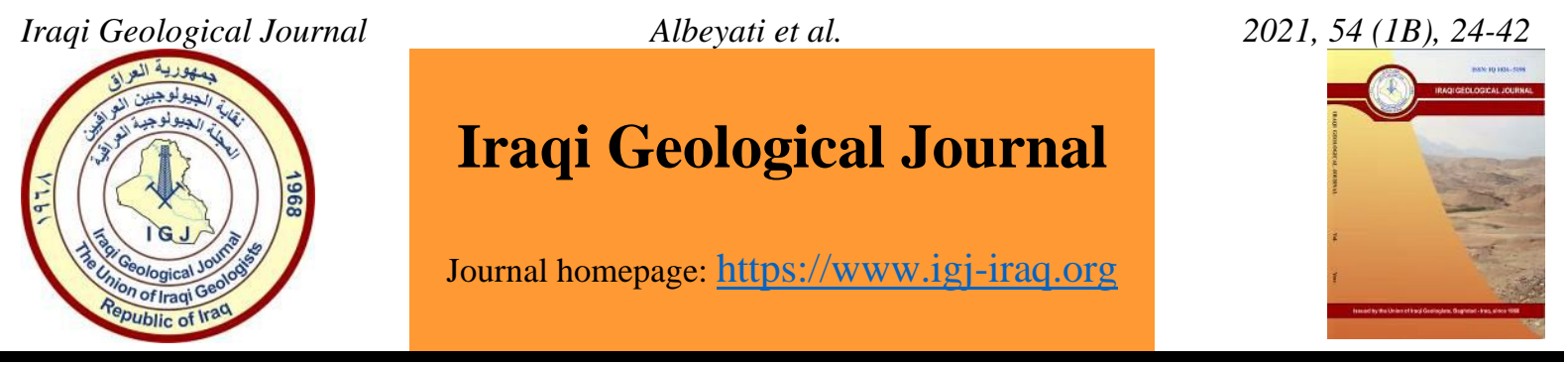

\title{
Porosity and Permeability Measurements Integration of The Upper Cretaceous in Balad Field, Central Iraq
}

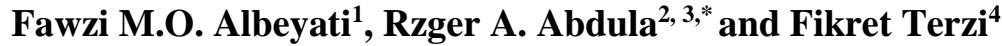 \\ ${ }^{1}$ Technical College of Kirkuk, North Technical University, Kirkuk, Iraq \\ ${ }^{2}$ Department of Petroleum Geoscience, University of Soran, Erbil, Iraq \\ ${ }^{3}$ Department of Petroleum Engineering and Mining, University of Tishik, Erbil, Iraq \\ ${ }^{4}$ Department of Petrol and Gas Engineering, University of Cyprus International, Lefkoşa, Cyprus \\ *Correspondence: rzger.abdulkarim@tiu.edu.iq
}

Received: 25 September 2020; Accepted: 7 December 2020; Published: 28 February 2021

\begin{abstract}
The corrected porosity image analysis and log data can be used to build 3D models for porosity and permeability. This can be much realistic porosity obtainable because the core test data is not always available due to high cost which is a challenge for petroleum companies and petrophysists. Thus, this method can be used as an advantage of thin section studies and for opening horizon for more studies in the future to obtain reservoir properties. Seventytwo core samples were selected and the same numbers of thin sections were made from Khasib, Sa`di, and Hartha, formations from Ba-1, Ba-4, and Ba-8 wells, Balad Oilfield in Central Iraq to make a comprehensive view of using porosity image analysis software to determine the porosity. The petrophysical description including porosity image analysis was utilized and both laboratory core test analysis and well log analysis were used to correct and calibrate the results. The main reservoir properties including porosity and permeability were measured based on core samples laboratory analysis. The results of porosity obtained from well log analysis and porosity image analysis method are corrected by using SPSS software; the results revealed good correlation coefficients between 0.684 and 0.872 . The porosity range values are $9-16 \%$ and $9-27 \%$ for Khasib and Sa'di in Ba-1 Well, respectively; 10$21 \%, 9-25 \%$, and $16-27 \%$ for Khasib, Sa'di and Hartha in Ba-4 Well, respectively; and $11-24 \%$ and $15-24 \%$ for Khasib and Hartha in Ba-8 Well, respectively according to petrographic image analysis. By using the laboratory core analysis, the porosity range values are $12-26 \%$ and $17-24 \%$ for Khasib and Sa'di in Ba-1 Well, respectively; 6-28\% and $14-27 \%$ for Sa'di and Hartha in Ba-4 Well, respectively; and $17-19 \%$ and $15-24 \%$ for Sa'di and Hartha in Ba-8 Well, respectively. Finally, the well log analysis showed that the porosity range values are 11-16\% and 7$27 \%$ for Khasib and Sa'di in Ba-1 Well, respectively; 4-18\%, 21-26\%, and 16-19\% for Khasib, Sa'di and Hartha in Ba-4 Well, respectively; and 9-24\% and $15-23 \%$ for Khasib and Hartha in Ba-8 Well, respectively. The permeability range values based on laboratory core analysis are 1.51-8.97 $\mathrm{md}$ and 0.29-2.77 $\mathrm{md}$ for Khasib and Sa'di in Ba-1 Well, respectively; 0.01-24.5 md and 0.28-6.47 md for Sa'di and Hartha in Ba-4 Well, respectively; and 0.86-2.25 md and 0.23-3.66 for Sa'di and Hartha in Ba-8 Well, respectively.
\end{abstract}

Keywords: Petrophysical properties; Petrographic image analysis; Porosity; Well logs

\section{Introduction}

Reservoir geology studies are important for exploration and field development plans (EDP and FDP). The hydrocarbon recovery factor of any reservoir is affected by the reservoir heterogeneities, and

DOI: $\underline{\text { 10.46717/igj.54.1B.3Ms-2021-02-21 }}$ 
the distributions of porosity and permeability (Chen et al. 2014). Many studies have been conducted to evaluate the carbonate reservoirs and their pore types targeting the investigation of reservoir quality (Al-Jawad and Kreem, 2016; Al-Majid, 2019; Al-Qayim, 2010). The pore types are affected by the organic activities and post-depositional diagenesis process including dissolution, cementation, recrystallization, and replacement (Janjuhah et al. 2017). Different studies were done on the Khasib, Sa'di and Hartha formations. Al-Zaidy et al. (2013), Al-Jawad and Kareem (2016), Sadooni (1996, 2017), Mohammed (2018), Al-Majid, (2019), Al-Fandi et al. (2020), and Al-Haj (2020). These studies were focused on evaluating the Khasib, Sa'di, and Hartha formations by using sedimentological, petrophysical, and high resolution sequence stratigraphy in East Baghdad, Halifaya, Ahdab, Tikrit, and Samarra oilfields. No studies have been carried out on either the present study in Balad Oilfield except the study of Al-Qayim (2010) which was focused on microfacies analysis in Tikrit, Samarra, Balad, and East Baghdad oilfields. Based on available information, the reservoirs may be heterogeneous with limited information; thus, describing and evaluating their petrophysical characteristics might need exceptional approaches and techniques e.g. the fluids and movement of fluid (Becker et al., 2019). Balad Oilfield is one of the important oilfields in Central of Iraq which has been operated by the North Iraq Oil Exploration Company. This oilfield is situated in Salah Al-Din City and located nearly $65 \mathrm{~km}$ to the north of Baghdad (Fig. 1). The area is covered by the Pleistocene and recent sediments. These sediments consist of alluvial deposits and river terraces from silt and clay with intercalations of sand and gravel. The aim of present study is to evaluate the petrophysical characteristics of Balad Oilfield using an integrated approach of all available data including core data (porosity and permeability), well logs (gamma ray, density, and resistivity), and petrographic image analysis (PIA).

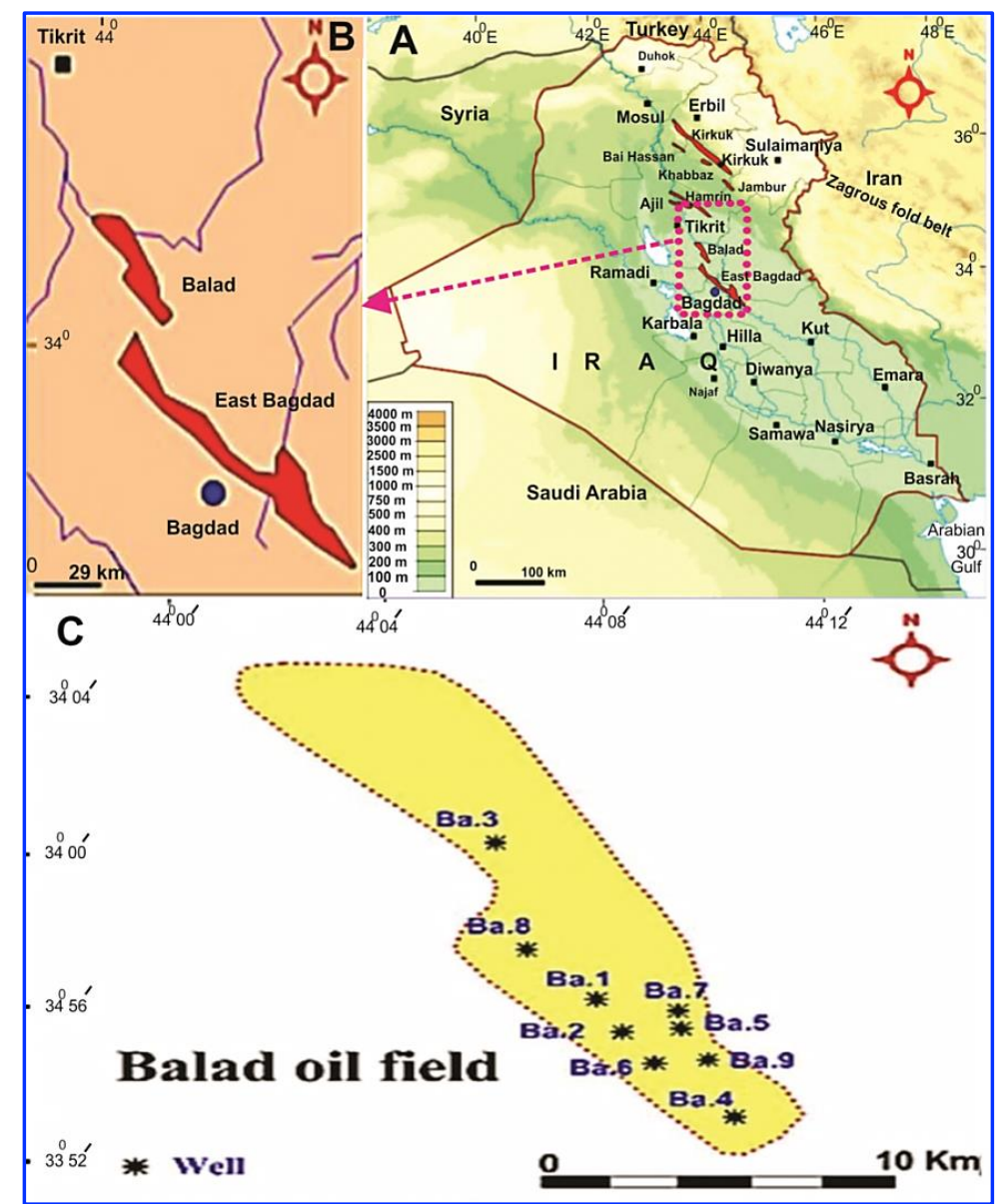

Fig. 1. A) Location map; B) Enlargement view outlined in A marked Baghdad and Salah Al-Din provinces; C) Balad Oilfield, Central Iraq (Albeyati et al., 2021). 


\section{Materials and Methodology}

The Khasib, Sa'di, and Hartha formations from Ba-1, Ba-4, and Ba-8 wells within the Balad Oilfield in Central Iraq were selected to apply the approach of this study. The comparison between the core tested data and PIA obtained from thin sections data was used to determine the correlation coefficient (R) value and factors which can be used to correct the PIA data and log data on the base of available core test data.

The laboratory core analysis method obtained from Weber (1987) can be summarized by measuring porosity and permeability over a very small sample of rock using a laboratory mini permeameters. This instrument measures the rate of air flow from a small-diameter tube (approximately 1-mm aperture) into and through the rock. This air-flow rate can then be related to rock permeability through calibration. PIA is a common tool for studying and measuring the pores' types and shape in addition to estimating the porosity values (Ehrlich et al., 1984; Anselmetti et al., 1998). One of the main goals of present work is to evaluate and estimate the pores' types and shape as an indicator of reservoir features of the Khasib, Sa'di, and Hartha carbonate formations. To analyze the pores types and to estimate the porosity using PIA, 73 thin sections were prepared and made with blue epoxy at Egyptian Petroleum Research Institute (EPRI). This approach was used by Ehrlich et al. (1984) and Anselmetti et al. (1998). The image analysis system was completed in the EPRI. It consists of a Sony DXC-290, CCD color video camera mounted on an Olympus petrographic microscope, and then the camera was used to capture the images under plane and cross-polarized light (PPL and XPL). Then it is imported to a PC prepared with a graphics card. Inspection of the images through the microscope was focused on viewing and subsequent capture by the image analysis system (Fig. 2). The measurement procedures were analogous on all thin sections tested. The proportion of the summation of the pore spaces versus the space of the entire image which refer to the total optical porosity (TOP) will be displayed (Ehrlich et al., 1984). Ten images were taken from each thin-section. The porosity's type and shape were estimated by averaging the results of the ten measurements for each sample. The image with the porosity rate that best fits the average porosity was further inspected and tabulated as it was the best typical model image of the thin sections (Anselmetti et al., 1998). A calibrated slide was observed under several magnifications and the superlative results for a wide range of measurement sizes were found to be 12.5 diameters. This exaggeration was accomplished with a $2.5 \mathrm{X}, 4 \mathrm{X}$, and $10 \mathrm{X}$. This exaggeration was exclusively used for this work (Anselmetti et al., 1998). The frequency distribution of the pores as well as the size and shape measurements allows quantitative analysis of carbonate rock.

Based on Choquette and Pray (1970) and Flügel (2004) classifications, the porosity in the image categorized into size and shape and listed in groups after determination of the aspect ratio and roundness factor. Then, the number of groups selected was indicated by the number of pore types in the sample. This study constructed to calculate the important petrophysical parameters needed for reservoir properties evaluation e.g. porosity $(\Phi)$, permeability, and water saturation $\left(S_{\mathrm{w}}\right)$. Calculation of the gamma-ray index (IGR) is the first step needed to determine the volume of shale $\left(\mathrm{V}_{\mathrm{sh}}\right)$ for the Khasib, Sa'di, and Hartha formations in Balad Oilfield from a gamma-ray log (Asquith, 2012) by using the following equation:

$$
\mathrm{I}_{\mathrm{GR}}=\frac{\mathrm{GR}_{\log }-\mathrm{GR}_{\min }}{\mathrm{GR}_{\max }-\mathrm{GR}_{\min }}
$$

Where $\mathrm{I}_{\mathrm{GR}}$ is gamma ray index; $\mathrm{GR}_{\log }$ is the gamma ray log read at the desired depth and calculate the volume of shale; $\mathrm{GR}_{\min }$ is the minimum read of gamma ray $\log$ at the clean part of shale (clean carbonate rocks); and $\mathrm{GR}_{\max }$ is the maximum read of gamma ray log at the high content shale part. For Pre-Tertiary consolidated rocks, the equation becomes: 


$$
\mathrm{V}_{\mathrm{Sh}}=0.33\left[2^{2 \times \mathrm{I}_{\mathrm{GR}}}-1\right]
$$

Density $\log$ is one of the common logs that are used for porosity measurement by measuring the electron density. The instrument consists of one or more of a gamma ray radiation sources from a specified distance from the source. The emitted gamma rays collide with the electrons in the rock-unit causing in the loss of energy, some energy lost in the formation. The others that reach to the recipient counted as evidence of the density formation (Asquith and Gibson, 1982). The most important uses of the density $\log$ are to determine the evaporator minerals, determine the gas zones, and quantify the density of hydrocarbons (Asquith and Gibson, 1982). For calculating the porosity from density log, the Wyllie's (1963) equation can be employed:

$$
\Phi_{\text {Dcorrection }}=\frac{\mathrm{P}_{\mathrm{ma}}-\mathrm{P}_{\mathrm{b}}}{\mathrm{P}_{\mathrm{ma}}-\mathrm{P}_{\mathrm{f}}}-\mathrm{V}_{\mathrm{sh}}\left[\frac{\mathrm{P}_{\mathrm{ma}}-\mathrm{P}_{\mathrm{sh}}}{\mathrm{p}_{\mathrm{ma}}-\mathrm{P}_{\mathrm{f}}}\right]
$$

$\Phi_{\mathrm{D}}$ is porosity derived from density log; $\rho$ ma is matrix density in $\mathrm{g} / \mathrm{cm}^{3}$ and recoup for carbonate rocks (2.710), dolomite (2.877), and anhydrite (2.977) (Asquith and Gibson, 1982; Asquith, 2012); $\rho$ b is the total formation density; and $\rho$ is fluid density, where it is 1.1 for the salinity clay, 1.0 for fresh clay, and 0.7 for gas in $\mathrm{g} / \mathrm{cm}^{3}$ (Asquith and Gibson, 1982; Asquith, 2012).

Resistivity is the resistance of a matter against the electric current path determined between contrary faces of a unit cube of the matter at identified temperature. It is expressed in ohm.m, more frequently abbreviated to ohm-meter. The resistivity logs measure the resistivity of the fluid. Therefore, the fluid can be distinguished whether there is oil (high resistivity) or water (low resistivity).

The formation water resistivity is calculated by the ratio method from the Asquith's (2012) equation:

$$
\mathrm{R}_{\mathrm{w}}=\frac{\left(\mathrm{R}_{\mathrm{t}} \times \mathrm{R}_{\mathrm{mf}}\right)}{\mathrm{R}_{\mathrm{xo}}}
$$

To correct the resistivity of mud cake $\left(\mathrm{R}_{\mathrm{mc}}\right)$ and mud filtrate $\left(\mathrm{R}_{\mathrm{mf}}\right)$, the different fluids can be used according to formation temperature using Arps' (1953) formula:

$$
\mathrm{R}_{\mathrm{w} 2}=\mathrm{R}_{\mathrm{w} 1} \times \frac{\left(\mathrm{T}_{1}+6.77\right)}{\left(\mathrm{T}_{2}+6.77\right)}
$$

$\mathrm{Rw}_{1}$ and $\mathrm{Rw}_{2}$ are formation water resistivity at temperatures $T_{1}$ and $T_{2}$. The determination of rock resistivity $\left(R_{\mathrm{xo}}\right.$ and $\left.\mathrm{R}_{\mathrm{t}}\right)$ based on the distance of invasion is divided into flushed zone resistivity $\left(\mathrm{R}_{\mathrm{xo}}\right)$ and true (uninvaded) zone resistivity $\left(\mathrm{R}_{\mathrm{t}}\right)$. The flushed zone resistivity $\left(\mathrm{R}_{\mathrm{xo}}\right)$ was measured by microphysical focused log (MSFL). The correction of flushed zone resistivity $\left(\mathrm{R}_{\mathrm{xo}}\right)$ depends on the calculation of the correction factor (C) which depends on the thickness of mud cake (hmc). According to Bateman and Konen (1978), the resistivity (R) is calculated from the basic formula:

$$
\mathrm{R}_{\mathrm{xo}}=\log _{10}\left[\frac{\mathrm{R}_{\mathrm{MSFL}}}{\mathrm{R}_{\mathrm{mc}}}\right]
$$

Finally, the $\mathrm{R}_{\mathrm{xo}}$ is corrected using the following equation:

$\mathrm{R}_{\mathrm{xo}}=\mathrm{CR}_{\mathrm{mcf}}$, where,

$\mathrm{C}$ is correction factor, $\mathrm{R}$ is resistivity, and mcf is mud cake filtrate.

The uninvaded zone resistivity $\left(\mathrm{R}_{\mathrm{t}}\right)$ was measured through deep induction $\log$ (IDL) and dual laterolog (LLD). The resistivity values are corrected for the borehole effect by using the following mathematical equations of Bateman and Konen (1978): 


$$
\begin{aligned}
\text { RLLD }(\text { Corr }) & =\text { CRLLD } \\
\text { RLLS }(\text { Corr }) & =\text { CRLLS }
\end{aligned}
$$

Where $\mathrm{C}$ is the correction factor which depends upon the hole diameter. The formation resistivity factor provides a useful and convenient way to clarify the nature of the pore structure of reservoir rocks. For determination of the formation resistivity factor (F) using Archie's (1942) formula as follow:

$$
\mathrm{F}=\frac{\mathrm{R}_{\mathrm{o}}}{\mathrm{R}_{\mathrm{w}}}
$$

The presence of shale in formation will cause to record a low resistivity log. Hilichie (1978) stated that "the most effect of shale in a formation is to reduce the resistivity contrast between oil or gas, and water". Water saturation $\left(S_{\mathrm{w}}\right)$ is the proportion of pore volume in a rock which is engaged by formation water. It denotes a significant log analysis conception due to the fact that the hydrocarbon saturation of any hydrocarbon reservoir can be calculated by subtracting water saturation from the value one, where $1.0=100 \%$ water saturation. In the clean formation, the water saturation $\left(S_{\mathrm{w}}\right)$ of uninvaded zone is calculated by Archie's (1942) formula:

$$
S_{\mathrm{w}}=\left[\frac{\mathrm{ax} \mathrm{R}}{\Phi^{\mathrm{m}} \mathrm{R}_{\mathrm{t}}}\right]^{1 / \mathrm{n}}
$$

In the flushed zone water saturation $\left(\mathrm{S}_{\mathrm{xo}}\right)$ and in clean zones, the water saturation of the flushed zone $\left(S_{\mathrm{xo}}\right)$ can be used as an indicator of hydrocarbon movability and can be calculated by using the equation above. The determination of the fluid saturation either in the uninvaded zone $\left(S_{\mathrm{w}}\right)$ or in the flushed zone $\left(S_{\mathrm{xo}}\right)$ facilitates, calculation of the hydrocarbon saturation, can be determined by using the following equation:

$$
S_{h}=1-S_{w}
$$

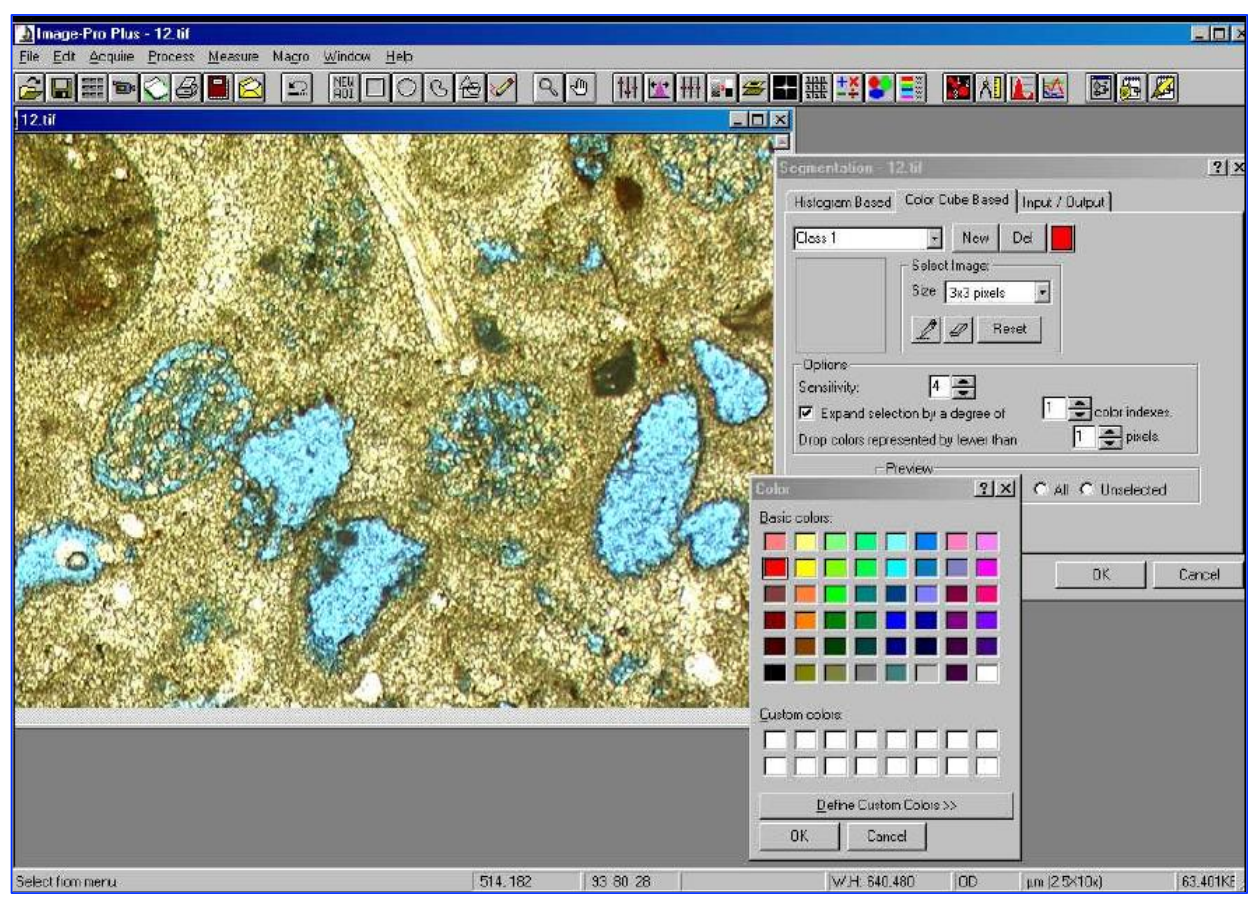

Fig. 2. Screen capture of image in color-separation style. The cursor was positioned on every pore (blue) pixels of that blue color in addition to extra pixels of that color in the image 


\section{Results and Discussions}

The core test data is not available for all wells due to its expensive cost; therefore, corrected PIA and $\log$ data can be used to build 3D models which can cover all the Balad Oilfield.

\subsection{Petrographic Image Analysis}

The results of the petrographic image analysis (PIA) summarized in Table 1. The Table 1 shows that the Khasib Formation porosity in Ba-1, Ba-4, and Ba-8 wells ranges between 9-16\%, 10-21\%, and $11-24 \%$, respectively with an average of approximately $17 \%$. The porosity types were intercrystalline and the porosity formed from the irregular distribution of early and late dissolution that resulted from the digenesis processes including vugs and channel porosity (Fig. 3).

Table 1. The result of the PIA from Sa'di, Khasib and Hartha formations, Balad Oilfield

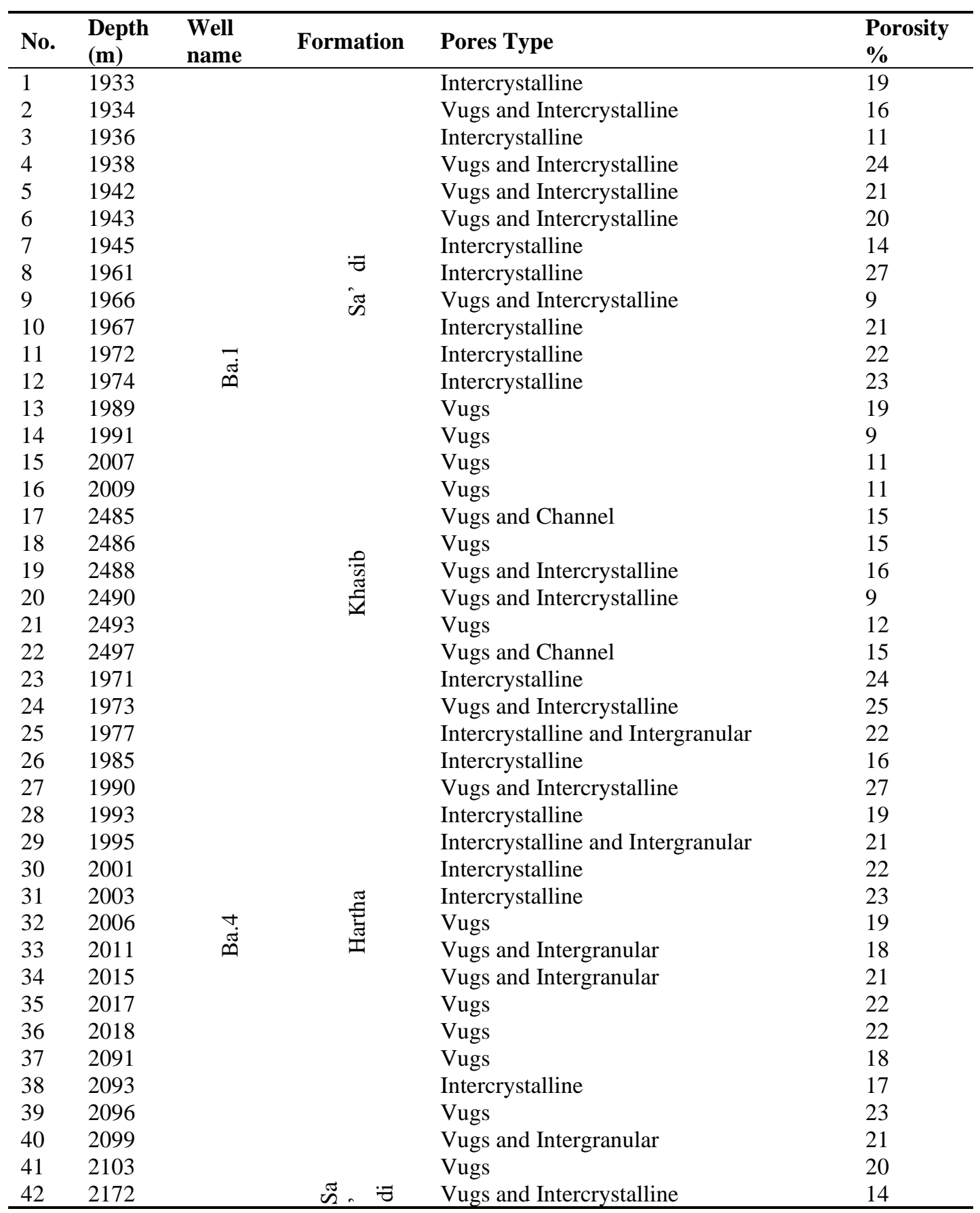




\begin{tabular}{ll}
43 & 2177 \\
44 & 2180 \\
45 & 2182 \\
46 & 2185 \\
47 & 2189 \\
48 & 2192 \\
49 & 2526 \\
50 & 2528 \\
51 & 2530 \\
52 & 2533 \\
53 & 2535 \\
54 & 2544 \\
55 & 2562 \\
56 & 2564 \\
57 & 1909 \\
58 & 1910 \\
59 & 1912 \\
60 & 1913 \\
61 & 1915 \\
62 & 1920 \\
63 & 1922 \\
64 & 1921 \\
65 & 2444 \\
66 & 2445 \\
67 & 2446 \\
68 & 2447 \\
69 & 2449 \\
70 & 2450 \\
71 & 2452 \\
72 & 2458 \\
\hline &
\end{tabular}

\begin{tabular}{|c|c|c|}
\hline & Intercrystalline & 25 \\
\hline & Vugs & 9 \\
\hline & Vugs & 21 \\
\hline & Intercrystalline & 22 \\
\hline & Vugs & 23 \\
\hline \multirow{9}{*}{ 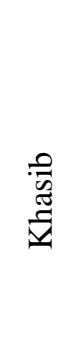 } & Vugs & 19 \\
\hline & Vugs and Channel & 16 \\
\hline & Vugs & 10 \\
\hline & Vugs & 12 \\
\hline & Intercrystalline & 15 \\
\hline & Intercrystalline & 19 \\
\hline & Vugs and Channel & 20 \\
\hline & Intercrystalline & 21 \\
\hline & Vugs and Channel & 20 \\
\hline \multirow{7}{*}{ 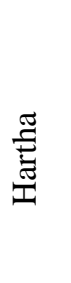 } & Vugs & 23 \\
\hline & Vugs and Intergranular & 22 \\
\hline & Vugs and Intercrystalline & 24 \\
\hline & Intercrystalline & 16 \\
\hline & Vugs & 17 \\
\hline & Vugs and Intercrystalline & 19 \\
\hline & Intercrystalline & 17 \\
\hline \multirow{9}{*}{ 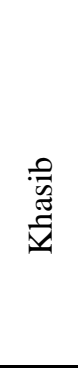 } & Vugs & 15 \\
\hline & Vugs & 24 \\
\hline & Vugs, Channel Intercrystalline & 21 \\
\hline & Vugs and Intercrystalline & 22 \\
\hline & Intercrystalline & 23 \\
\hline & Vugs & 19 \\
\hline & Vugs and Intercrystalline & 13 \\
\hline & Intercrystalline & 12 \\
\hline & Vugs & 11 \\
\hline
\end{tabular}

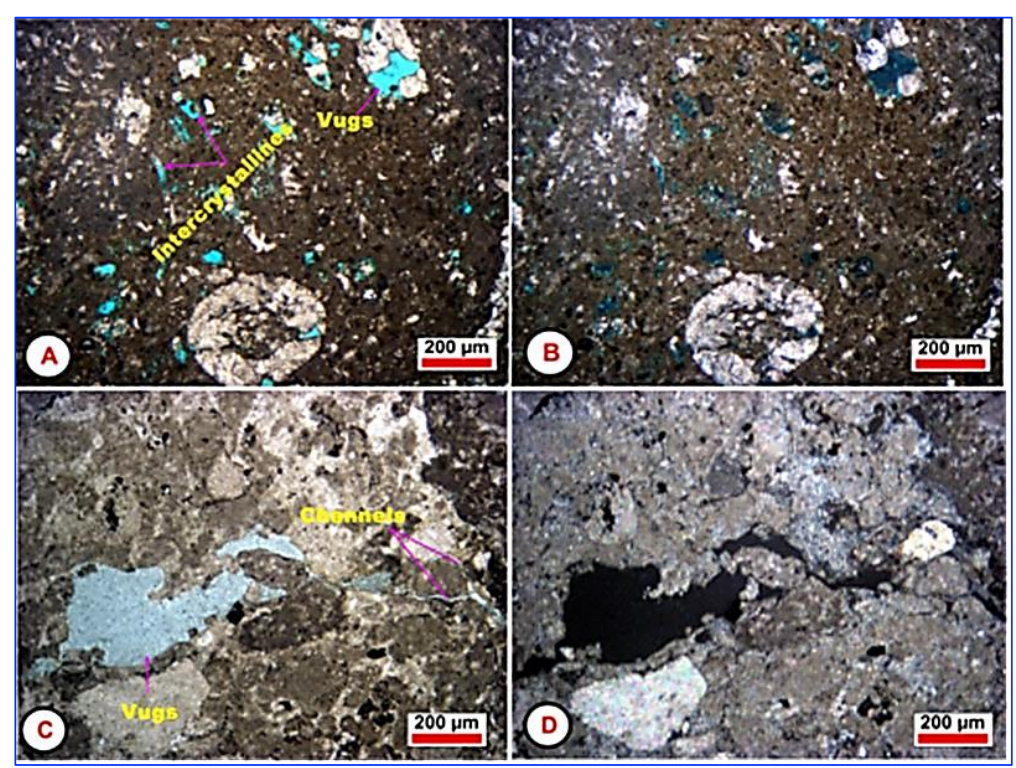

Fig. 3. Core photo from Khasib Formation, well Ba-4, Balad Oilfield (2526-2564 m). A) PPL photo; B) XPL photo showing the intercrystalline and vugs porosity; C) PPL photo; and D) XPL photo showing the vugs and channels porosity

The Sa'di Formation porosity in Ba-1 and Ba-4 wells ranges between 9-27\% and 9-25\% (Table 1), respectively with an average of nearly $18 \%$. The pore types are vugs and intercrystalline (Fig. 4). The Hartha Formation porosity in Ba-4 and Ba- 8 wells ranges between $16-27 \%$ to $15-24 \%$, respectively 
with an average of about $21 \%$ (Table 1). The porosity types are vugs, intercrystalline, and channels. The porosity existing within the carbonate rocks was affected by recrystallization (Tucker and Wright, 1990) (Fig. 5). From above, it can be concluded that the Hartha Formation has the highest porosity values followed by Sa'di and Khasib formations, respectively. The possible reason is that the Hartha Formation is the most affected by the dissolution and diagenesis processes which were more than Sa'di and Khasib formations. Generally, the porosity types e.g. molded and vug represent environmental effect, because these two types can be described from or at the sequence boundary due to a slow rate of sedimentation (Morad et al., 2012). In addition to the fact that Khasib and Sa'di formations represent basinal facies which was characterized by slow rate of deposition (Al-Qayim, 2010). This could give ways to the diagenesis processes to enlarge the molded porosity at first to vugs and then to channel porosity (Asquith, 2012), while the intercrystalline porosity creation may be due to the effect of dolomitization on high surface area of basinal micrite supported facies.

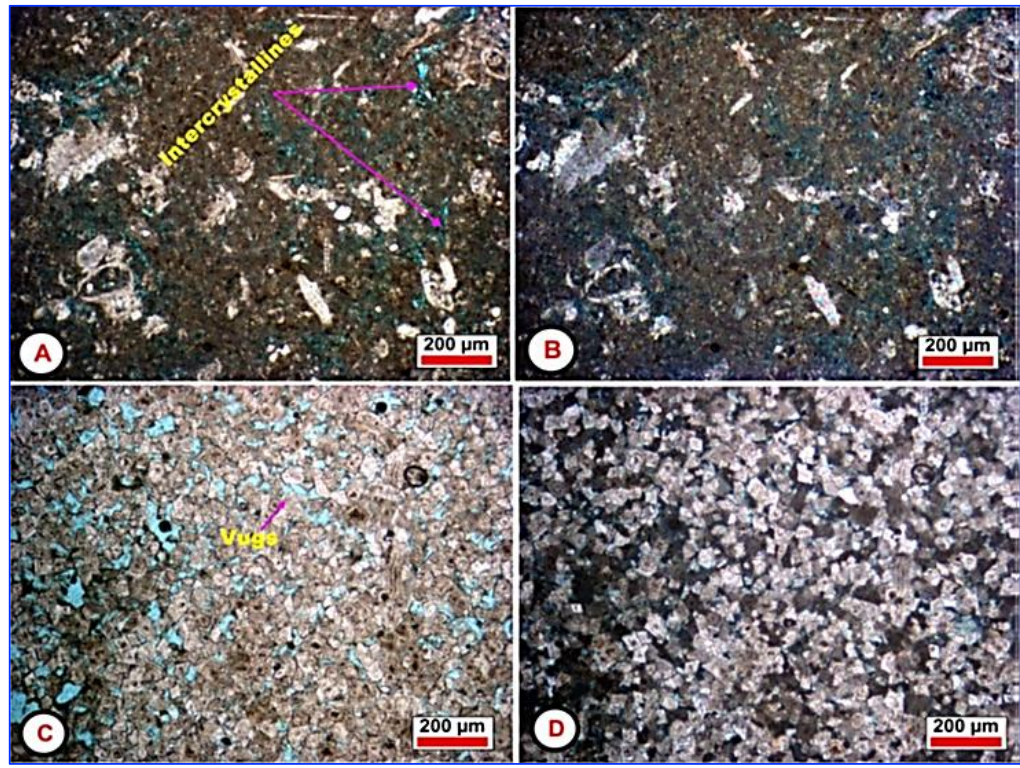

Fig. 4. Core photo from Sa'di Formation, well Ba-1, Balad Oilfield (1933-2009 m). A) PPL photo; B) XPL photo shows the intercrystalline porosity; C) PPL photo; and D) XPL photo of the vugs porosity

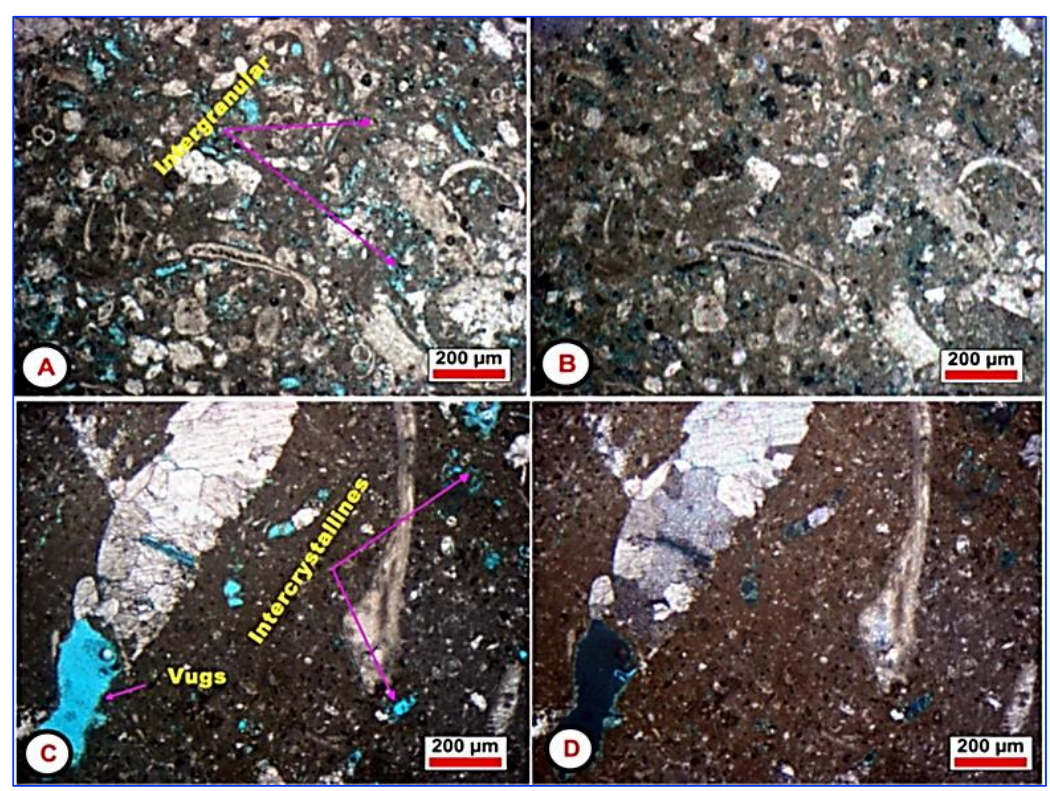

Fig. 5. Core photo from Hartha Formation, well Ba-8, Balad Oilfield (1909-1921 m). A) PPL photo; B) XPL photo showing the intercrystalline porosity; C) PPL photo; and D) XPL photo showing the vugs and intercrystalline porosity 


\subsection{Laboratory Core Analysis}

Laboratory core analysis includes several measurements with the objective of obtaining information about multiphase flow behavior. It gives detailed information about the distribution of oil, gas, and water in the reservoir; furthermore, the residual oil saturation and multiphase flow characteristics. However, the method is expensive and tedious, but it is still the most direct way of obtaining rock properties because the results from indirect methods like logs need to be calibrated against results obtained by core analysis. Laboratory core analysis attempts to extend the data provided by traditional measurements to be more representative of reservoir conditions. It is used to support log and well test data in gaining an understanding of individual well and overall reservoir performance. The main reservoir rock properties including porosity and permeability will be described in Table 2 .

Table 2. Laboratory core analysis of the Hartha, Khasib and Sa'di formations in Balad Oilfield

\begin{tabular}{|c|c|c|c|c|c|c|}
\hline No. & Well name & Formation & $\begin{array}{l}\text { Depth } \\
\text { (m) }\end{array}$ & $\begin{array}{l}\text { Air Permeability } \\
\text { (md) }\end{array}$ & $\begin{array}{l}\text { Porosity } \\
\%\end{array}$ & $\begin{array}{l}\text { Grain density } \\
\mathrm{g} / \mathrm{cc}\end{array}$ \\
\hline 1 & & & 1933 & 0.53 & 19 & 2.692 \\
\hline 2 & & & 1934 & 0.29 & 17 & 2.694 \\
\hline 3 & & & 1942 & 1.79 & 23 & 2.693 \\
\hline 4 & & $: 7$ & 1943 & 0.99 & 23 & 2.693 \\
\hline 5 & & $\pi$ & 1966 & 0.45 & 17 & 2.707 \\
\hline 6 & & $\stackrel{\pi}{\infty}$ & 1974 & 2.77 & 24 & 2.693 \\
\hline 7 & & & 1989 & 0.82 & 19 & 2.694 \\
\hline 8 & $I$ & & 1991 & 0.51 & 17 & 2.704 \\
\hline 9 & $\tilde{\varphi}$ & & 2007 & 1.95 & 23 & 2.702 \\
\hline 10 & & & 2009 & 2.21 & 25 & 2.695 \\
\hline 11 & & & 2327 & 8.97 & 25 & 2.695 \\
\hline 12 & & $=$ & 2336 & 3.99 & 23 & 2.695 \\
\hline 13 & & $\overline{\mathfrak{z}}$ & 2338 & 5.32 & 21 & 2.702 \\
\hline 14 & & $\tilde{v}$ & 2338 & 4.48 & 26 & 2.702 \\
\hline 15 & & & 2341 & 1.51 & 21 & 2.704 \\
\hline 16 & & & 2346 & 1.65 & 21 & 2.701 \\
\hline 17 & & & 1971 & 1.12 & 18 & 2.692 \\
\hline 18 & & & 1973 & 0.49 & 17 & 2.694 \\
\hline 19 & & & 1990 & 6.47 & 27 & 2.693 \\
\hline 20 & & & 1995 & 1.91 & 22 & 2.693 \\
\hline 21 & & $\stackrel{\widetilde{J}}{\underline{E}}$ & 2006 & 4.14 & 27 & 2.693 \\
\hline 22 & & 壱 & 2017 & 1.27 & 20 & 2.693 \\
\hline 23 & & & 2018 & 0.28 & 14 & 2.694 \\
\hline 24 & & & 2091 & 1.66 & 20 & 2.704 \\
\hline 25 & & & 2093 & 1.97 & 20 & 2.702 \\
\hline 26 & & & 2103 & 4.29 & 21 & 2.695 \\
\hline 27 & 壵 & & 2104 & 3.65 & 23 & 2.695 \\
\hline 28 & & & 2116 & 3.91 & 24 & 2.699 \\
\hline 29 & & & 2117 & 1.53 & 19 & 2.696 \\
\hline 30 & & & 2125 & 0.23 & 14 & 2.701 \\
\hline 31 & & $:=$ & 2133 & 1.23 & 18 & 2.694 \\
\hline 32 & & & 2134 & 1.36 & 19 & 2.690 \\
\hline 33 & & $\tilde{\mathscr{n}}$ & 2140 & 0.72 & 13 & 2.705 \\
\hline 34 & & & 2141 & 0.92 & 12 & 2.694 \\
\hline 35 & & & 2143 & 0.01 & 6 & 2.693 \\
\hline 36 & & & 2182 & 4.53 & 25 & 2.686 \\
\hline 37 & & & 2187 & 24.5 & 28 & 2.689 \\
\hline 38 & & & 1909 & 0.71 & 18 & 2.702 \\
\hline 39 & & $\stackrel{\Xi}{E}$ & 1910 & 3.66 & 24 & 2.696 \\
\hline 40 & & 氞 & 1915 & 3.46 & 22 & 2.693 \\
\hline 41 & $\infty$ & & 1921 & 0.23 & 15 & 2.707 \\
\hline 42 & $\stackrel{\tilde{n}}{\oplus}$ & & 2444 & 2.25 & 17 & 2.692 \\
\hline 43 & & 7 & 2447 & 0.86 & 17 & 2.693 \\
\hline 44 & & $\pi$ & 2452 & 1.36 & 19 & 2.697 \\
\hline 45 & & & 2458 & 2.06 & 19 & 2.695 \\
\hline
\end{tabular}


The analysis was done on core interval samples selected from Khasib, Sa'di, and Hartha formations in Ba-1, Ba-4, and Ba-8 wells within Balad Oilfield. The analysis was provided by the EPRI. The results display that the Khasib Formation porosity and permeability in well Ba-1 range between 12$26 \%$ and 1.51-8.97 md (Table 2), respectively with an average porosity of $18.5 \%$ and average permeability of $5.24 \mathrm{md}$. The Sa'di Formation porosity and permeability results in Ba-1 range between 17-24\% and 0.29-2.77 md (Table 2), while in Ba-4 Well range between 6-28\% and 0.01-24.5 md (Table 2 ), and in Ba-8 range between 17-19\% and 0.86-2.25 md (Table 2), respectively. The average porosity and permeability for the Sa'di Formation in the three studied wells were $18.5 \%$ and $5.11 \mathrm{md}$, respectively. The Hartha Formation characterized generally by high value of porosity and permeability due to its location at the boundary of new sequence package. Therefore, it is characterized by vug porosity. The second reason is that the Hartha Formation consists of grain supported reef facies (Sadooni, 2017); thus, the formation has high values of the both porosity and permeability (Asquith, 2012). The Hartha Formation porosity and permeability in well Ba-4 range between $14-27 \%$ and 0.28 $6.47 \mathrm{md}$ (Table 2), while in Ba-8 they range between 15-24\% and 0.23-3.66 md (Table 2), respectively. The average porosity and permeability for the Hartha Formation in Ba- 4 and Ba- 8 wells is $20 \%$ and 2.65 md, respectively. A commonly observed trend is the increase of permeability with porosity increase. The cross plot of porosity versus permeability (Fig. 6) demonstrate a positive log-linear correlation of increasing permeability with increasing porosity from all studied core samples of Khasib, Sa'di, and Hartha formations within Balad Oilfield. The association of porosity with permeability emphasize on the existence of vugs, intercrystalline, and chanel porosity types. This result reveals very good to excellent matching with the obtained results by PIA method in this study due to faraway location of all represented values of permeability versus porosity from $\mathrm{Y}$ axis.

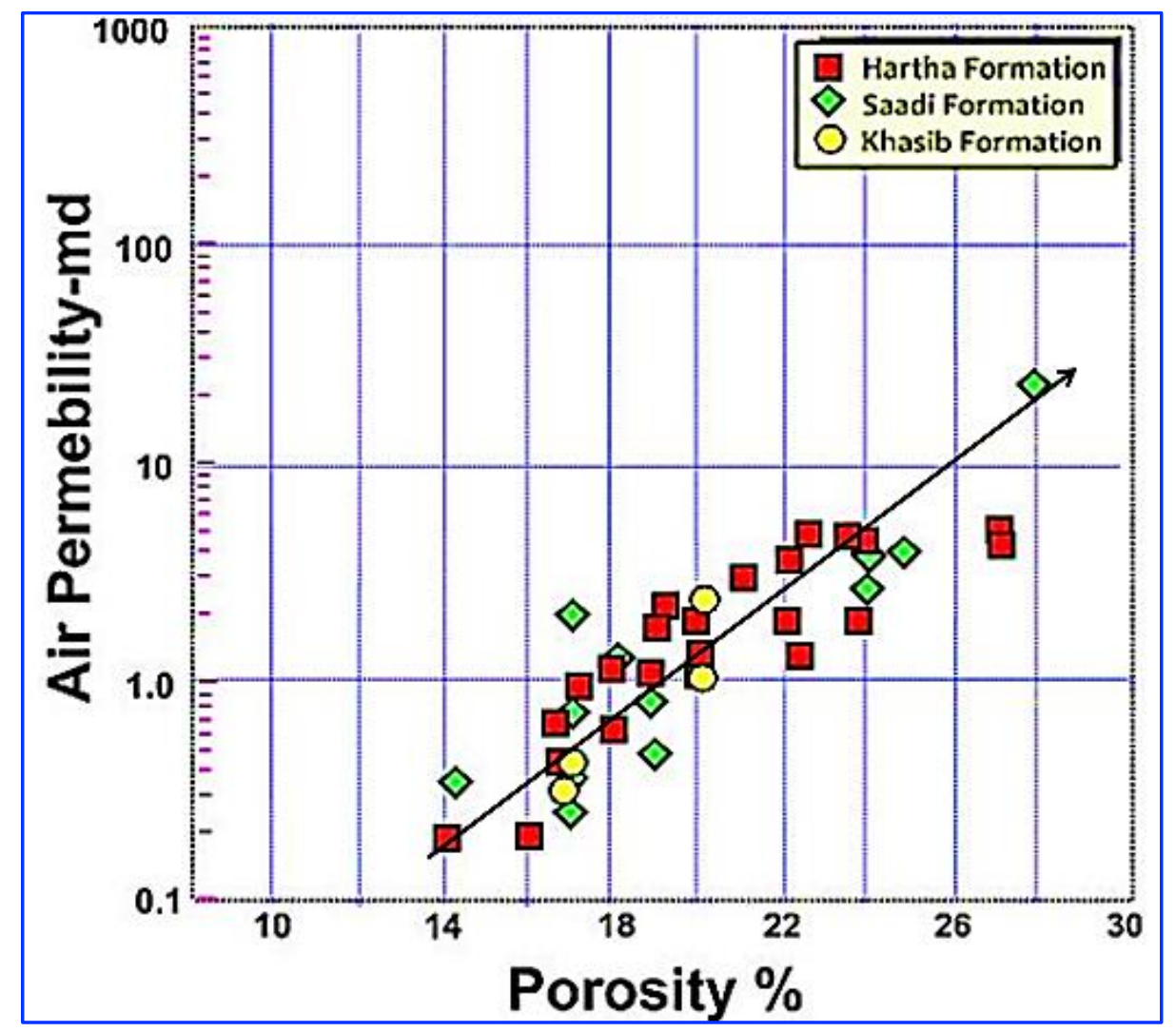

Fig. 6. Cross plot showing the typical core tested porosity versus core tested permeability trend for carbonate reservoir formations of the Balad Oilfield 


\section{3. Well Log Analysis}

Wire line logging is performed after an interruption or the termination of drilling activity, and is thus distinguished from drilling-logs (Serra, 1984). Log interpretation is the process by which these measurable parameters are translated into the desired petrophysical parameters. Well log examination is the main performance for every well to disclose the reservoir rock units amongst the entirely drilled intervals. Their conventional uses in hydrocarbon exploration are to correlate zones and assisting the structure and isopach mapping. Well logs are the main tools that can be used to describe physical rock features including lithology, porosity, pore geometry, water saturation, and permeability. They are used to recognize pay zones; define depth and thickness of pay zone; differentiate oil, gas, or water from each other in a reservoir; and evaluate the reserved petroleum capacity. Gamma ray log is used for determining the volume of shale effect (more than 10\%) to correct all data obtained from well logs viz. density and resistivity logs to data visualization the three reservoirs of Balad Oilfield (Khasib, Sa'di, and Hartha formations) from Ba-1, Ba-4, and Ba-8 wells (Table 3 and Figs. 7, 8, and 9). The Khasib Formation shale volumes in $\mathrm{Ba}-1, \mathrm{Ba}-4$, and $\mathrm{Ba}-8$ wells range between 1-3\%, 2-17\%, and 1-15\% with an average of $6.5 \%$ (Table 3); the porosity values range between $11-16 \%, 4-18 \%, 9-24 \%$ and with an average of $13.7 \%$ (Table 3); and the water saturation expanses range between 92-98\%, 31-97\%, and 47$68 \%$ with an average of $72.2 \%$, respectively (Table 3). The shale volume of Sa'di formation in Ba-1 and Ba-4 wells ranges between 1-18\% and 1-1\% with an average of $4.5 \%$ (Table 3); the porosity values range between $7-27 \%$ and $21-26 \%$ with an average of $20.3 \%$ (Table 3); and the water saturation ranges between 5-58\% (average 21.3\%) and 67-76\% (average 70.9\%) (Table 3). The Hartha Formation shale volumes in Ba-4 and Ba- 8 wells are $1 \%$ for both with an average of $1 \%$ (Table 3); the porosity values range between 15-19\% (average 18.9\%) and 15-23\% (average 19.5) (Table 3); and the water saturation amounts range between $26-58 \%$ and $32-51 \%$ with an average of almost $47 \%$, respectively (Table 3 ).

Table 3. Gamma ray, density, and resistivity logs data of the Hartha, Khasib and Sa'di formations

\begin{tabular}{|c|c|c|c|c|c|c|}
\hline No. & $\begin{array}{c}\text { Depth } \\
\text { (m) }\end{array}$ & $\begin{array}{c}\text { Well } \\
\text { name }\end{array}$ & Formation & $\begin{array}{l}\text { Volume of } \\
\text { shale (\%) }\end{array}$ & $\begin{array}{c}\text { Porosity } \\
\%\end{array}$ & $\begin{array}{c}\text { Water saturation } \\
\%\end{array}$ \\
\hline 1 & 1933 & & & 12 & 15 & 31 \\
\hline 2 & 1934 & & & 14 & 17 & 24 \\
\hline 3 & 1936 & & & 12 & 18 & 21 \\
\hline 4 & 1938 & & & 18 & 22 & 10 \\
\hline 5 & 1942 & & & 15 & 21 & 8 \\
\hline 6 & 1943 & & & 14 & 21 & 8 \\
\hline 7 & 1945 & & & 12 & 27 & 5 \\
\hline 8 & 1961 & & 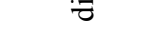 & 15 & 23 & 28 \\
\hline 9 & 1966 & & $\pi$ & 13 & 15 & 36 \\
\hline 10 & 1967 & & & 17 & 18 & 19 \\
\hline 11 & 1972 & $I$ & & 8 & 7 & 58 \\
\hline 12 & 1974 & صే & & 4 & 24 & 18 \\
\hline 13 & 1989 & & & 1 & 21 & 14 \\
\hline 14 & 1991 & & & 1 & 20 & 20 \\
\hline 15 & 2007 & & & 5 & 18 & 20 \\
\hline 16 & 2009 & & & 7 & 14 & 21 \\
\hline 17 & 2485 & & & 1 & 12 & 98 \\
\hline 18 & 2486 & & & 1 & 16 & 92 \\
\hline 19 & 2488 & & : & 1 & 13 & 92 \\
\hline 20 & 2490 & & $\tilde{\Xi}$ & 1 & 12 & 98 \\
\hline 21 & 2493 & & & 3 & 11 & 98 \\
\hline 22 & 2497 & & & 2 & 13 & 98 \\
\hline 23 & 1971 & & & 1 & 17 & 63 \\
\hline 24 & 1973 & & & 1 & 25 & 24 \\
\hline 25 & 1977 & & $\tilde{I}$ & 1 & 23 & 27 \\
\hline 26 & 1985 & స్ర & 产 & 1 & 24 & 30 \\
\hline 27 & 1990 & & $\bar{I}$ & 1 & 20 & 32 \\
\hline 28 & 1993 & & & 1 & 20 & 45 \\
\hline 29 & 1995 & & & 1 & 22 & 35 \\
\hline
\end{tabular}




\begin{tabular}{|c|c|c|c|c|c|}
\hline 30 & 2001 & & 1 & 24 & 29 \\
\hline 31 & 2003 & & 1 & 23 & 26 \\
\hline 32 & 2006 & & 1 & 23 & 31 \\
\hline 33 & 2011 & & 1 & 11 & 79 \\
\hline 34 & 2015 & & 1 & 23 & 34 \\
\hline 35 & 2017 & & 3 & 14 & 81 \\
\hline 36 & 2018 & & 2 & 22 & 39 \\
\hline 37 & 2091 & & 1 & 19 & 26 \\
\hline 38 & 2093 & & 1 & 18 & 34 \\
\hline 39 & 2096 & & 1 & 18 & 31 \\
\hline 40 & 2099 & & 1 & 16 & 39 \\
\hline 41 & 2103 & & 1 & 16 & 34 \\
\hline 42 & 2104 & & 1 & 17 & 36 \\
\hline 43 & 2116 & & 1 & 16 & 51 \\
\hline 44 & 2117 & & 1 & 15 & 51 \\
\hline 45 & 2125 & & 1 & 16 & 48 \\
\hline 46 & 2133 & & 1 & 18 & 43 \\
\hline 47 & 2134 & & 1 & 17 & 42 \\
\hline 48 & 2140 & & 1 & 18 & 55 \\
\hline 49 & 2141 & & 1 & 17 & 42 \\
\hline 50 & 2143 & & 1 & 17 & 58 \\
\hline 51 & 2172 & & 1 & 21 & 67 \\
\hline 52 & 2177 & & 1 & 23 & 67 \\
\hline 53 & 2180 & $=$ & 1 & 24 & 76 \\
\hline 54 & 2182 & $=$ & 1 & 24 & 76 \\
\hline 55 & 2185 & $\mathscr{\pi}$ & 1 & 23 & 68 \\
\hline 56 & 2189 & & 1 & 25 & 72 \\
\hline 57 & 2192 & & 1 & 26 & 76 \\
\hline 58 & 2526 & & 17 & 15 & 97 \\
\hline 59 & 2528 & & 6 & 18 & 97 \\
\hline 60 & 2530 & & 2 & 13 & 31 \\
\hline 61 & 2533 & $\frac{0}{3}$ & 2 & 11 & 41 \\
\hline 62 & 2535 & $\frac{\pi}{\pi}$ & 2 & 12 & 42 \\
\hline 63 & 2544 & & 2 & 4 & 98 \\
\hline 64 & 2562 & & 2 & 14 & 58 \\
\hline 65 & 2564 & & 2 & 10 & 97 \\
\hline 66 & 1909 & & 1 & 15 & 45 \\
\hline 67 & 1910 & & 1 & 18 & 36 \\
\hline 68 & 1912 & & 1 & 22 & 32 \\
\hline 69 & 1913 & $\stackrel{\mathbb{E}}{=}$ & 1 & 19 & 33 \\
\hline 70 & 1915 & 营 & 1 & 23 & 35 \\
\hline 71 & 1920 & & 1 & 22 & 34 \\
\hline 72 & 1921 & & 1 & 20 & 40 \\
\hline 73 & 1922 & $\infty$ & 1 & 17 & 51 \\
\hline 74 & 2444 & $\ddot{\oplus}$ & 1 & 11 & 47 \\
\hline 75 & 2445 & & 15 & 21 & 52 \\
\hline 76 & 2446 & & 1 & 24 & 49 \\
\hline 77 & 2447 & $\frac{0}{2}$ & 1 & 9 & 54 \\
\hline 78 & 2449 & $\frac{\pi}{2}$ & 6 & 17 & 62 \\
\hline 79 & 2450 & & 1 & 11 & 61 \\
\hline 80 & 2452 & & 1 & 11 & 68 \\
\hline 81 & 2458 & & 1 & 16 & 57 \\
\hline
\end{tabular}

Through the average results of the shale volume, porosity, and water saturation of the three reservoirs, the Hartha Formation has the least shale volume (1\%), and this finally reflected on the relativity of higher porosity average $(19.2 \%)$ with the lowest water saturation $\left(S_{\mathrm{w}}\right), 47 \%$. This is due to higher hydrocarbon saturation in wells Ba-4 and Ba-8. So, it can be considered that Hartha Formation has the most promising hydrocarbon accumulations in the Balad Oilfield, followed by Khasib and Sa'di formations. This is due to Hartha Formation containing grain supported rocks (Fig. 5) in addition to its dominant reef facies, while the Sa'di Formation represents the basinal facies and the Khasib Formation represents ramp facies (Al-Qayim, 2010). 


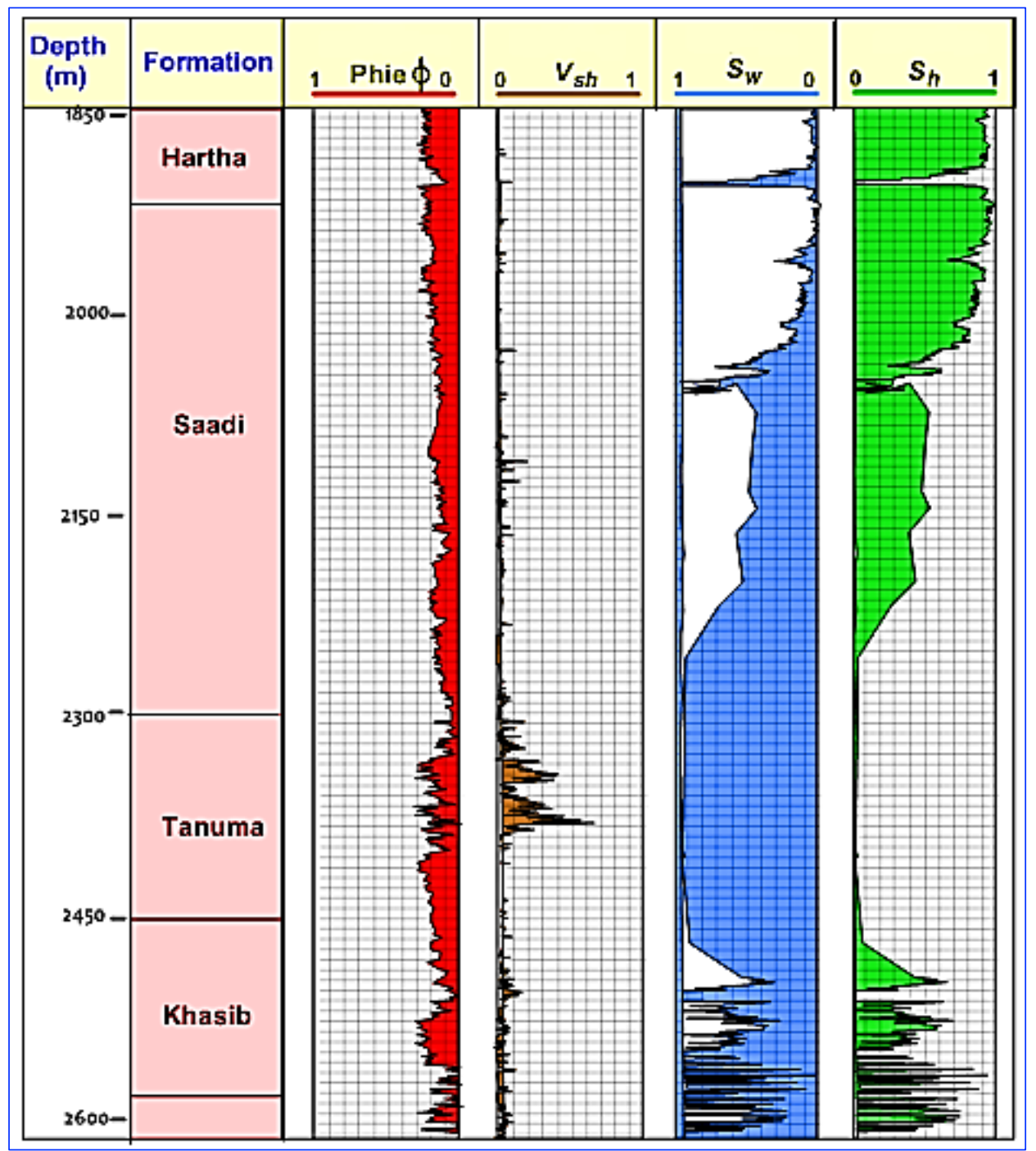

Fig. 7. Petrophysical calculations of the Ba-1 Well, Balad Oilfield including density derived porosity (Phi), shale volume (Vsh), water saturation ( $\mathrm{Sw})$, and hydrocarbon saturation (Sh)

\subsection{Correlation the Petrophysical Analysis Data}

The petrophysical analysis techniques of the reservoirs could be categorized into three groups: 1) petrographic image analysis (PIA) of the thin sections; 2) core tested plug samples; and 3) well logs calculations. The integration of the results obtained from these analyses has been done to build up a complete picture of the Khasib, Sa'di, and Hartha formations within the Balad Oilfield by determining the main features for each given horizon. The statistical processing by using Statistical Package for the Social Sciences (SPSS) software program through using an available porosity as one important from two petrography factors to determine the correlation coefficient $(\mathrm{R})$ and fundamentals of test statistics e.g. F test and $\mathrm{T}$ test. In Ba-1 well, the results of correlated core porosity with predicted log porosity that were obtained from SPSS software represented by formula equation (1a) (Tables 4, 5 and Fig. 10a) showing good correlation coefficient $\left(\mathrm{R}^{2}=0.826\right)$, and $(\mathrm{Std}$. Error $=0.115)$. The result from correlated core porosity with the measured petrographic image porosity represented by formula equation (1b) (Tables 4, 5 and Fig. 10b), the correlation coefficient $\left(R^{2}=0.872\right)$ and (Std. Error $\left.=0.103\right)$, indicated good correlation coefficient with the neglected error as its clear from $\mathrm{F}$ and $\mathrm{T}$ tests. 


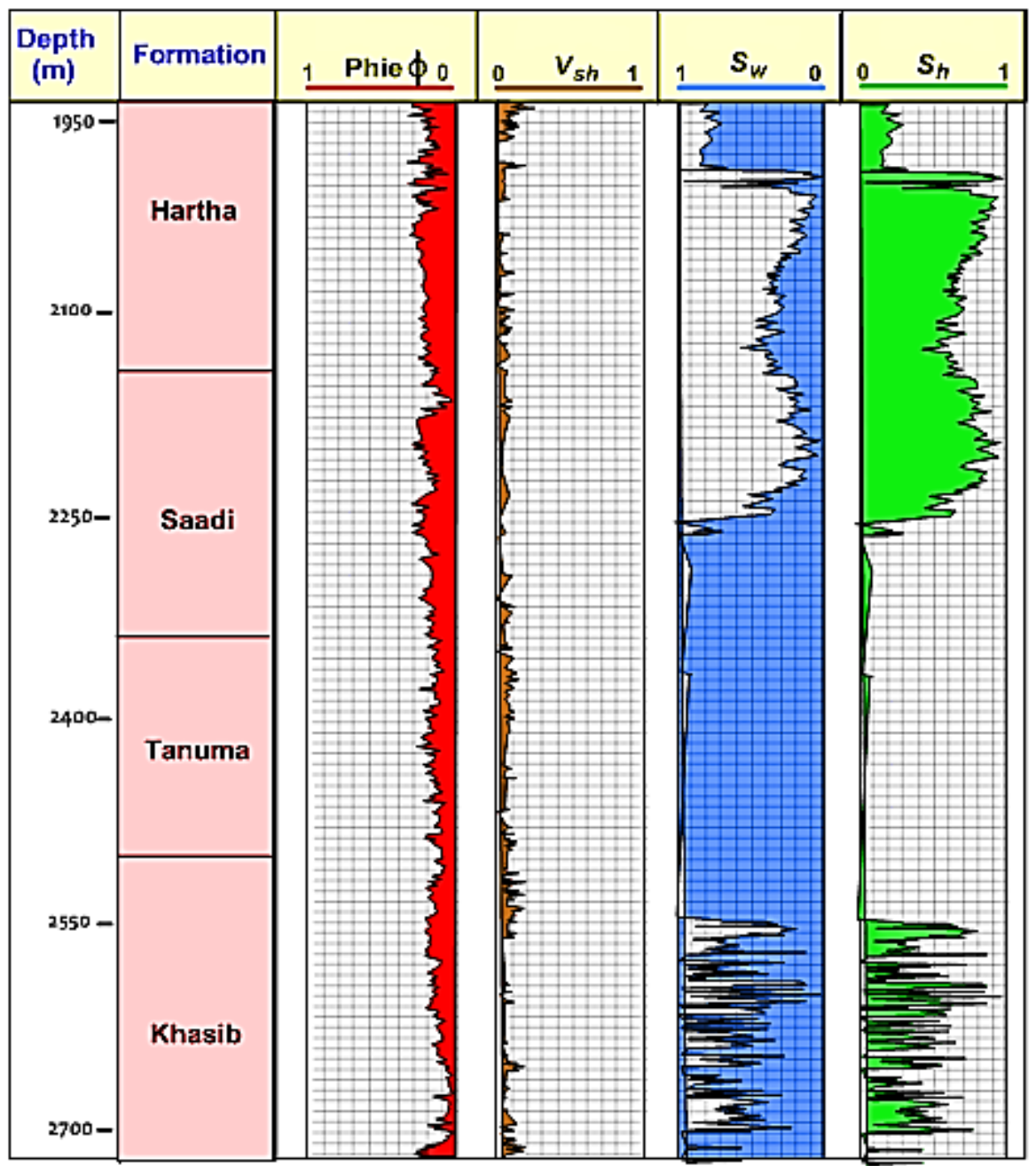

Fig. 8. Petrophysical calculations of the Ba-4 Well, Balad Oilfield including density derived porosity (Phi), shale volume (Vsh), water saturation ( $\mathrm{Sw})$, and hydrocarbon saturation $(\mathrm{Sh})$

Table 4. Model summary of the core and predicted porosity in wells Ba-1, Ba-4, and Ba- 8

\begin{tabular}{|c|c|c|c|c|c|c|c|c|c|}
\hline \multirow[t]{2}{*}{ Model } & \multirow[t]{2}{*}{$\mathrm{R}$} & \multirow{2}{*}{$\begin{array}{c}\mathrm{R} \\
\text { Square }\end{array}$} & \multirow{2}{*}{$\begin{array}{c}\text { Adjusted } \\
\text { R } \\
\text { Square } \\
\end{array}$} & \multirow{2}{*}{$\begin{array}{l}\text { Std. Error } \\
\text { of the } \\
\text { Estimate }\end{array}$} & \multicolumn{5}{|c|}{ Change Statistics } \\
\hline & & & & & $\begin{array}{l}\text { R Square } \\
\text { Change }\end{array}$ & $\begin{array}{c}\mathrm{F} \\
\text { Change }\end{array}$ & Df1 & Df2 & $\begin{array}{l}\text { Sig. F } \\
\text { Change }\end{array}$ \\
\hline \multicolumn{10}{|c|}{ Ba-1 } \\
\hline 1 & $0.909^{\mathrm{a}}$ & 0.826 & 0.818 & $\begin{array}{c}2.18174 \\
\text { dictors: (C }\end{array}$ & \multicolumn{2}{|c|}{ a. Predictors: (Constant), Logs } & 1 & 20 & 0.000 \\
\hline \multicolumn{10}{|c|}{$\begin{array}{l}\text { b. Predictors: (Constant), Image } \\
\text { Ba-4 }\end{array}$} \\
\hline \multicolumn{10}{|c|}{ a. Predictors: (Constant), Logs } \\
\hline \multicolumn{10}{|c|}{$\begin{array}{c}\text { b. Predictors: (Constant), Image } \\
\text { Ba- } 8\end{array}$} \\
\hline 1 & $0.910^{\mathrm{a}}$ & 0.828 & 0.815 & $\begin{array}{c}1.48073 \\
\text { dictors. (C }\end{array}$ & $\begin{array}{r}0.828 \\
\end{array}$ & 67.184 & 1 & 14 & 0.000 \\
\hline 1 & $0.902^{\mathrm{b}}$ & 0.814 & 0.801 & 1.53639 & 0.814 & 61.408 & 1 & 14 & 0.000 \\
\hline
\end{tabular}




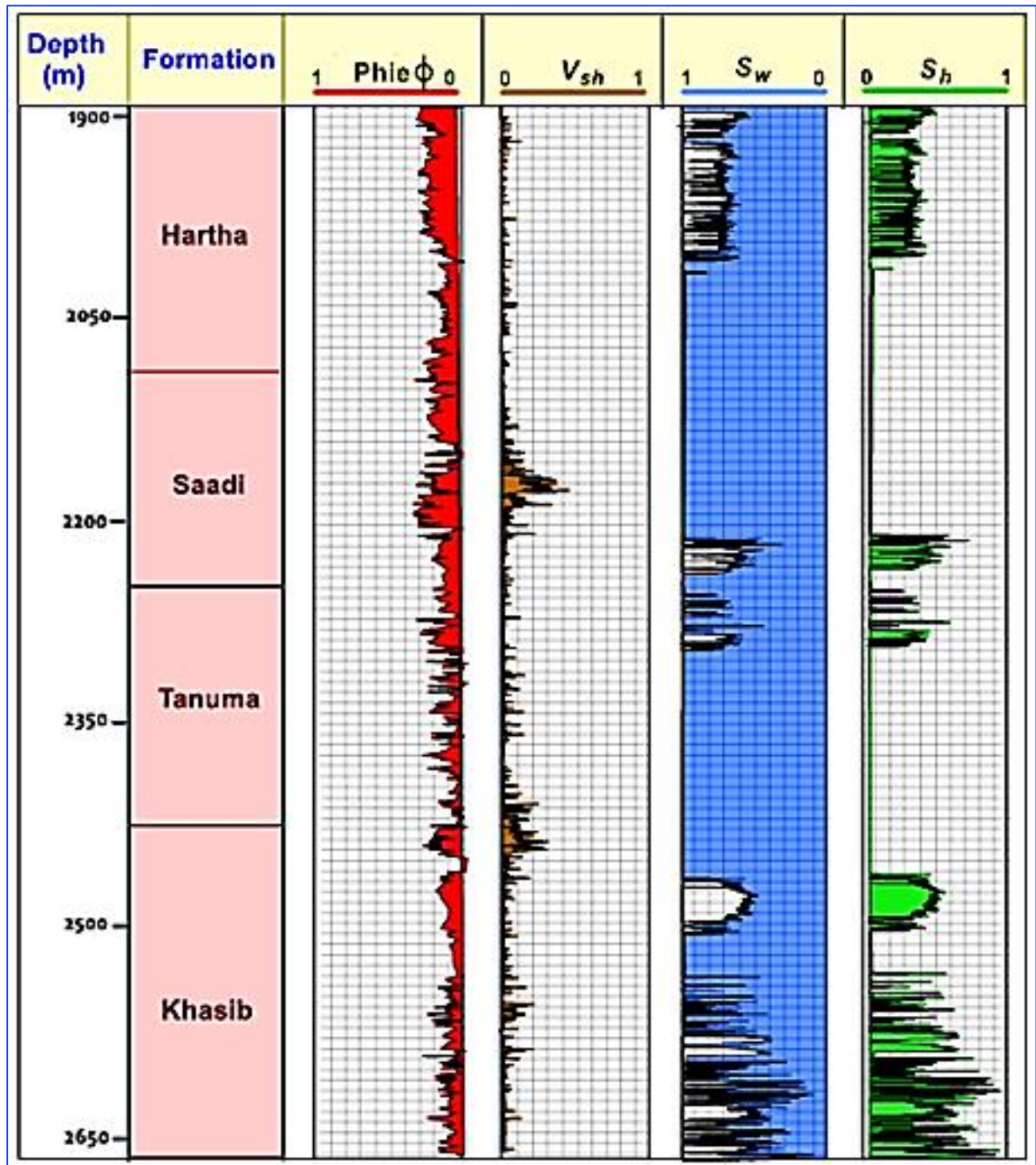

Fig. 9. Petrophysical calculations of the Ba- 8 Well, Balad Oilfield including density derived porosity (Phi), shale volume (Vsh), water saturation (Sw), and hydrocarbon saturation (Sh)

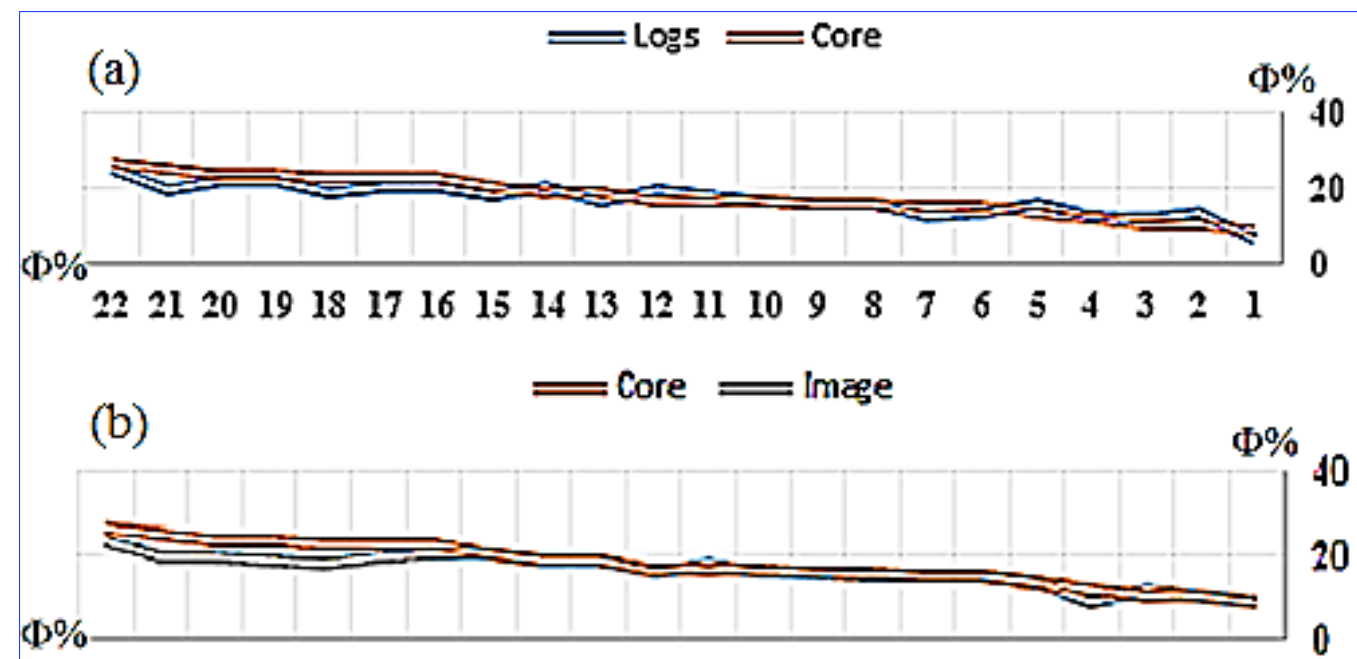

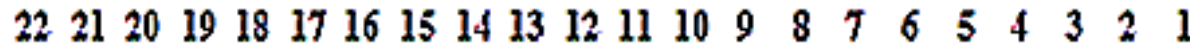

Fig. 10. Correlation coefficient between (a) core and predicted porosity and (b) cores and measured petrographic image from well log in Ba-1 Well 
In Ba-4 Well, the result of correlated core porosity with predicted log porosity represented by formula equation (2a) (Tables 4, 5 and Fig. 11a) $\left(R^{2}=0.780\right)$, and (Std. Error $\left.=0.082\right)$ showing good relation. The result from correlated core porosity with the measured petrographic image porosity represented by formula equation ( $2 b)$ (Tables 4,5 and Fig. $11 b)$, the correlation coefficient $\left(R^{2}=0.684\right.$ ) and (Std. Error $=0.098)$ showing fair relation. In Ba-8 Well, the result of correlated core porosity with predicted $\log$ porosity represented by formula equation (3a) (Tables 4, 5 and Fig. 12a) showing good correlation coefficient $\left(R^{2}=0.828\right)$ and $(S t d$. Error $=0.117)$. The result from correlated core porosity with the measured petrographic image porosity represented by formula equation (3b) (Tables 4, 5 and Fig. $12 b)$, the correlation coefficient $\left(R^{2}=0.814\right)$, and $($ Std. Error $=0.158)$ indicated good correlation coefficient.

Table 5. Coefficients of the core and predicted porosity in wells $\mathrm{Ba}-1, \mathrm{Ba}-2$, and $\mathrm{Ba}-8$

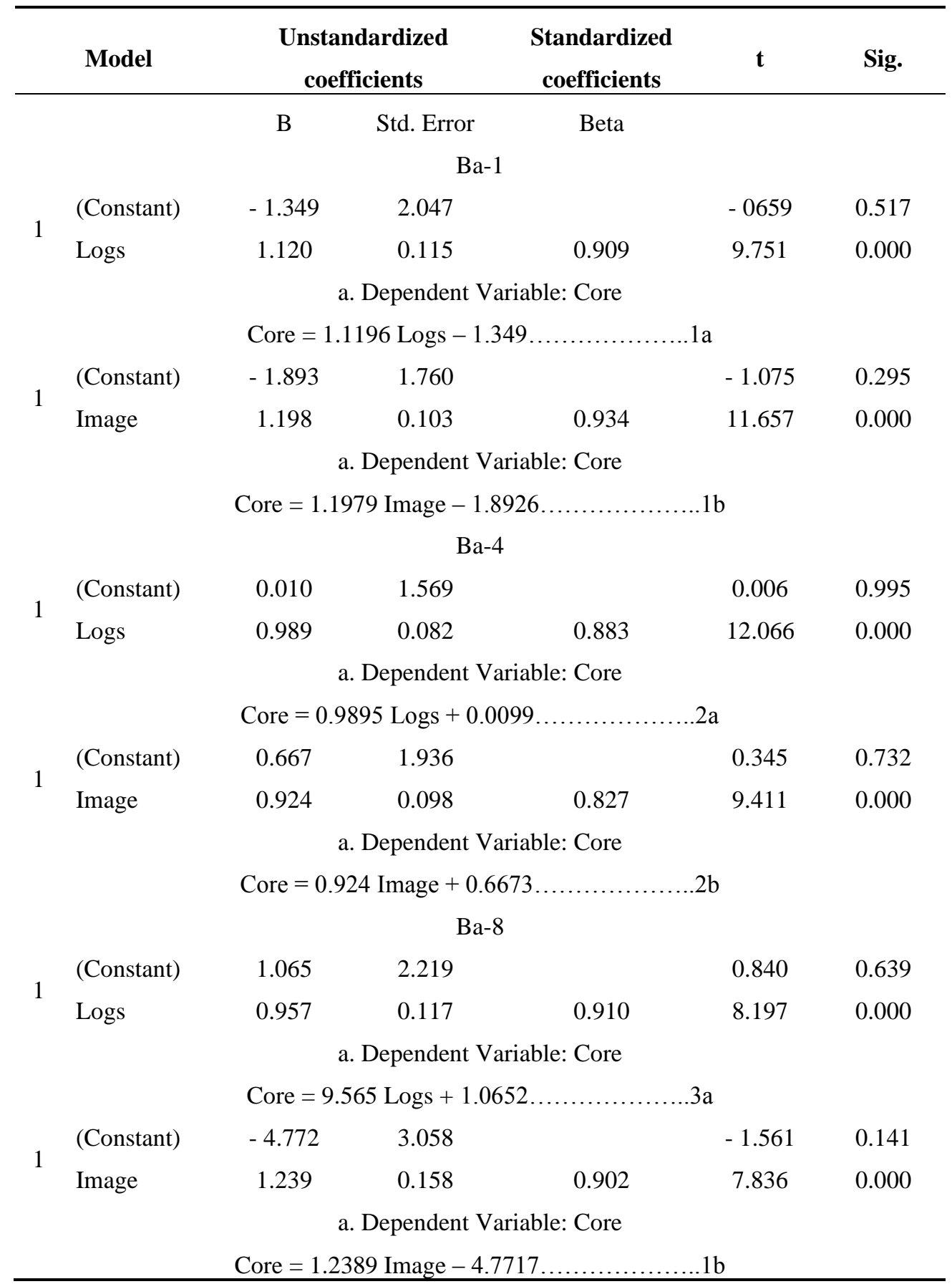




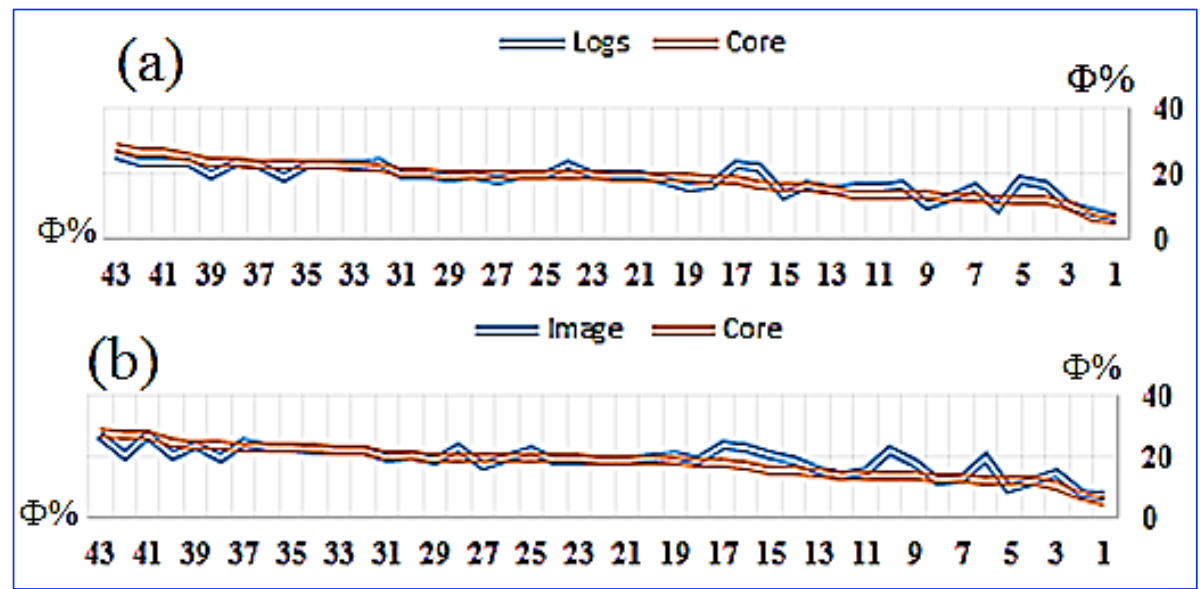

Fig. 11. Correlation coefficient between (a) core and predicted porosity from well log and (b) cores and measured petrographic image porosity in $\mathrm{Ba}-4$ Well

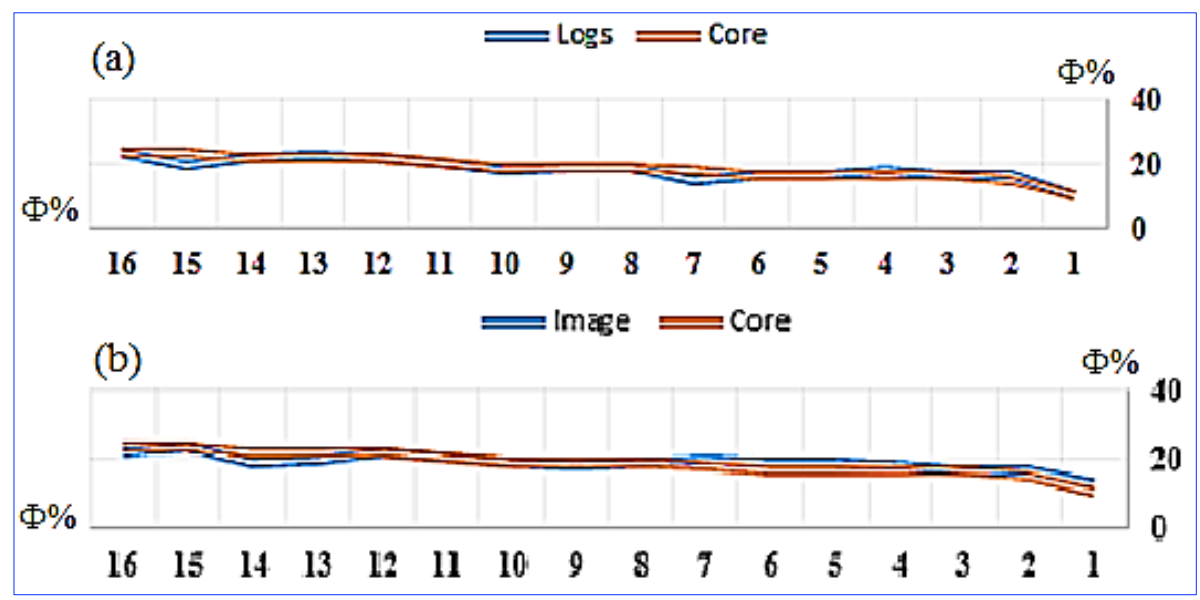

Fig. 12. Correlation coefficient between (a) core and predicted porosity from well log and (b) cores and measured petrographic image porosity in Ba- 8 Well.

\section{Conclusions}

The results of the correlations between the petrophysical analysis, the PIA method and core analysis revealed good correlations with negligible standard errors; therefore, the PIA method can be recommended to use in determining the approximate values of porosity as an advantage that can be obtained from thin sections studies. The porosity range values in Ba-1 Well are 9-16\%, 12-26\%, and $11-16 \%$ for Khasib Formation; 9-27\%, 17-24\%, and 7-27\% for Sa'di Formation by using the petrographic image analysis, laboratory core analysis, and well log analysis, respectively.

The porosity range values in Ba-4 Well are 10-21\%, 12-26\%, and 11-16\% for Khasib Formation; 9-25\%, 6-28\%, and 21-26\% for Sa'di Formation; and 16-27\%, 14-27\%, and 16-19\% for Hartha Formation by using the petrographic image analysis, laboratory core analysis, and well log analysis, respectively. The porosity range values in Ba- 8 Well are 11-24\% and 9-24\% for Khasib Formation by using the petrographic image analysis and well log analysis, respectively. The porosity range values are $17-19 \%$ for Sa'di Formation by using laboratory core analysis. The porosity range values are $15-24 \%$, $15-24 \%$, and $15-23 \%$ for Hartha Formation by using the petrographic image analysis, laboratory core analysis, and well log analysis, respectively. 
The integration of PIA, well logs, and core analysis revealed that the Hartha Formation has the most promising hydrocarbon reserves in Ba- 1 and Ba- 4 wells, followed by Sa'di and Khasib formations. The Ba- 8 Well shows that the Khasib Formation has the majority of reserved hydrocarbon where this formation has low water saturation value, while Sa'di Formation was fully saturated by water. The permeability range values based on laboratory core analysis are 1.51-8.97 md for Khasib Formation in Ba-1 Well; 0.29-2.77 md, 0.01-24.5 md, 0.86-2.25 md for Sa'di Formation in wells Ba-1, Ba-4, and Ba8, respectively; and 0.28-6.47 md and 0.23-3.66 md for Hartha Formation in Ba-4 and $\mathrm{Ba}-8$, respectively.

\section{Acknowledgements}

We would like to thank Egyptian Petroleum Research Institute (EPRI) in Egypt for its help with the image analysis system. The authors are very grateful to the Editor in Chief Prof. Dr. Salih M. Awadh, the Secretary of Journal Mr. Samir R. Hijab. and the Technical Editors for their great efforts and valuable comments.

\section{References}

Albeyati, F. M. O., Abdula, R. A., Othman, R. S., 2021. Organic geochemistry and source rocks evolution of the middle to upper Jurassic source rocks succession in Balad-1 Well, Balad Oil Field, Central Iraq, Bulletin of the Geological Society of Malaysia71, (In press).

Al-Fandi, E. I., Malak, Z. A., Hadid, N. A., 2020. Sequence stratigraphy, depositional environments and reservoir characterization of Sa'di Formation in East Baghdad and Halfiya oilfields, Iraqi Geological Journal 53(1), 21-35.

Al-Haj, M. A., 2020. Sedimentological study of the Hartha Formation in selected oilfields, northern Iraq, Iran Journal Science Transactions 40995(20), 831-845.

Al-Jawad, M. S., Kreem, K. A., 2016. Geological model of Khasib Reservoir- Central Area, East Baghdad Field, Iraqi Journal of Chemical and Engineering 17(3), 1-10.

Al-Majid, M. H. A., 2019. New petrophysical equations for Hartha-Tannuma interval in the East Baghdad Oil Field, Iraqi National Journal of Earth Science 2(19), 136-152.

Al-Qayim, B., 2010. Sequence stratigraphy and reservoir characteristics of the Turonian - Coniacian Khasib Formation in Central Iraq, Iraqi Journal of Petroleum Geology 33(4), 387-404.

Al-Zaidy, A. A., Sattam, M., Nasir, M. E., 2013. High resolution sequence stratigraphy and reservoir

characterization of the Hartha Formation in Ahdab Oilfield, Journal of Babylon University and Engineering Science 21(1), 37-49.

Anselmetti, F. S., Luthi, S., and Eberli, G. P., 1998. Quantitative characterization of carbonate pore systems by digital image analysis, AAPG Bulletin 82, 1815-1836.

Archie, G. E., 1942. The electrical resistivity $\log$ as an aid in determining some reservoir characteristics,

AIME Tech. Pub, 1422.

Arps, J. J., 1953. The effects of temperature on the density and electrical resistivity of sodium chloride solutions, Trans. AIME 198, 327-330.

Asquith, G., Gibson, C., 1982. Basic Well Log Analysis for Geologists: Methods in Exploration Series, AAPG Bulletin, 216p.

Asquith, G. B., 2012. Fundamentals of Petrophysical Well-Log Interpretation: A Course-Note Collection With Commentary, CreateSpace Independent Publishing Platform, 628p.

Bateman, R. M. Konen, C. E., 1978. Well Site Log Analysis and the Programmable Pocket Calculator. SPWIL $8^{\text {th }}$ Ann. Log. Symp., Houston, Texas, 107-123.

Becker, S., Reuning, L., Amthor, J. E., Kukla, P., 2019. Diagenetic processes and reservoir heterogeneity in saltencased microbial carbonate reservoir (Late Neoproterozoic, Oman). Geofluids, Article ID 5647857, 19p.

Chen, Ch., Balhoff, M., Mohanty, K.K., 2014. Effect of reservoir heterogeneity on primary recovery and $\mathrm{Co}_{2}$ huff ' $n$ ' puff recovery in shale-oil reservoirs, SPE Reservoir Evaluation \& Engineering, 404-413.

Choquette, P.W. Pray, L.C., 1970. Geologic nomenclature and classification of porosity in sedimentary carbonates, AAPG Bulletin 2, 207-250.

Ehrlich, R., Kennedy, S. K., Crabtree, S. J., Cannon, R. L., 1984. Petrographic image analysis; Analysis of reservoir pore complexes, Journal of Sedimentary Petrology 54, 136-1378.

Flügel, E., 2004. Microfacies of carbonate rocks: Analysis, interpretation and applications, Springer-Verlag, Berlin, 976p. 
Hilichie, D. W., 1978. Applied open hole interpretation. Golden, Colorado, D.W. Hilchie, Inc.

Janjuhah, H. T., Salim, A. M. A., Gosh, D. P., and Wahid, A., 2017. Diagenetic process and their effect on reservoir quality in Miocene carbonate reservoir, offshore Sarawak, Malaysia, in: Awang, M. Negash, B., Md. Akhir, N., Lubis, L., Md. Rafek, A. (Eds.). Springer, Singapore.

Mohammed, A. K., 2018. Reservoir characteristics of Khasib Formation in Amara Field, southern Iraq, Iraqi Geological Journal 51(2), 54-74.

Morad, S., Ketzer, J. M., and De Ros, L. F., 2012. Linking diagenesis to sequence stratigraphy: an integrated tool for understanding and predicting reservoir quality distribution, International Association of Sedimentologists, Special Publication 45, 1-36.

Sadooni, F. N., 1996. Stratigraphy and lithology characteristics of upper Cretaceous in central Iraq, Journal of Petroleum Geology 19, 271-288.

Sadooni, F. N., 2017. Impact of the demise mechanisms of the Cretaceous rudist buildups in the Arabian Plate on their reservoir characteristics. Carbonates Evaporates 33, 465-476.

Serra, O., 1984. Fundamentals of well-log interpretation. The Acquisition Logging Data, 1. Elsevier, 679p.

Tucker, M. E. and Wright, V. P., 1990. Carbonate sedimentology, Blackwell Science Ltd., Oxford, 496p.

Weber, K. J., 1987. Computation of initial well productivities in aeolian sandstone on the basis of a geological model, Leman Gas Field, U.K., in: Tillman, R.W. Weber, K.J. (Eds.), Reservoir sedimentology, Soc. Econ., Paleon. and Mineral. (SEPM) 40, 333-354.

Wyllie, M. R. J., 1963. The Fundamentals of Well Log Interpretation, New York Academic Press. 